\title{
Self-perception of older adults regarding rehabilitation with dentures
}

\author{
Autopercepção de idosos sobre a reabilitação \\ com próteses dentárias
}

Nélio Manoel Luiz de SÁ JÚNIOR' iD https://orcid.org/0000-0001-9152-2928
Silvana Maria Orestes CARDOSO' iD https://orcid.org/0000-0002-3175-0328

\section{ABSTRACT}

Objective: To analyze the self-perception that older adults have about rehabilitation regarding their uni or bimaxillary dentures. Methods: A form was applied to investigate the sociodemographic, economic and medical-dental variables of the users, a questionnaire to assess the satisfaction level of patients with their dentures, another to investigate the technical quality of the dentures from the aesthetic-functional point of view, and the Oral Health Impact Profile (OHIP-14) to ascertain the impact of prosthetic rehabilitation on the quality of life of users. Results: The majority of the participants (65.2\%) used complete bimaxillary dentures, reported dissatisfaction during chewing, while the lower dentures had unsatisfactory technical quality for the retention requirements (69.6\%) and stability (69.6\%). The older adults' complaints were predominantly related to the "physical pain" and "physical disability" domains. There were significant associations between general satisfaction with the dentures in use, their general technical quality and the OHIP-14 domains. Conclusion: The patient complaints were related to difficulties in their ability to chew, speak and with the retention and comfort of the lower dentures. The technical quality of the dentures had compromised retention and stability from the aesthetic-functional point of view. Dentures considered unsatisfactory caused negative impacts on the quality of life of users, especially in comfort during meals which was related to difficulty chewing and swallowing. The association between the instruments used in the study provides important tools for the performance of dental surgeons, in addition to enabling more adequate planning in the oral health services offered to the population.

Indexing terms: Denture, complete. Quality of life. Patient satisfaction.

\section{RESUMO}

Objetivo: Analisar a autopercepção que os idosos têm sobre a reabilitação com suas próteses dentárias totais uni ou bimaxilares. Métodos: Aplicou-se um formulário para investigar as variáveis sociodemográficas, econômicas e médico-odontológicas dos usuários, um questionário para avaliar o nível de satisfação dos pacientes com seus aparelhos protéticos, outro para investigar a qualidade técnica das próteses, do ponto de vista estético-funcional, e o Oral Health Impact Profile (OHIP-14), para averiguar o impacto da reabilitação protética na qualidade de vida dos usuários. Resultados: A maioria dos participantes $(65,2 \%)$ utilizava prótese total dupla, relatava insatisfação durante a mastigação, os aparelhos protéticos inferiores apresentavam qualidade técnica insatisfatória para os requisitos de retenção $(69,6 \%)$ e estabilidade $(69,6 \%)$. As queixas dos idosos estavam relacionadas, predominantemente, aos domínios "dor física" e "incapacidade física". Houve associações significativas entre a satisfação geral com a prótese em uso, a qualidade técnica geral

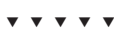

1 Universidade Federal de Pernambuco, Faculdade de Odontologia, Departamento de Prótese e Cirurgia Buco-Facial. Av. Prof. Moraes Rego, 1235. Cidade Universitária, 52670-90, Recife, PE, Brasil. Correspondece to: NML SÁ JÚNIOR. E-mail: <neliojunior1000@hotmail.com>.

$\boldsymbol{\nabla} \boldsymbol{\nabla} \boldsymbol{\nabla}$

How to cite this article

SÁ JÚNIOR NML, CARDOSO SMO. Self-perception of older adults regarding rehabilitation with dentures. RGO, Rev Gaúch Odontol. 2021;69:e20210053. http://dx.doi.org/10.1590/1981-863720210005320200020
} 
das mesmas e os domínios do OHIP-14. Conclusão: As queixas dos pacientes estavam relacionadas com dificuldades na capacidade de mastigar, falar e com a retenção e o conforto das próteses totais inferiores. A qualidade técnica dessas próteses, do ponto de vista estético-funcional, apresentava retenção e estabilidade comprometidas. Os aparelhos protéticos considerados insatisfatórios causaram impactos negativos na qualidade de vida dos usuários, sobretudo, no conforto durante as refeições, o qual estava relacionado à dificuldade na mastigação e deglutição. A associação entre os instrumentos utilizados no estudo fornece ferramentas importantes para a atuação do cirurgião-dentista, além de possibilitar um planejamento mais adequado nos serviços de saúde bucal oferecidos à população.

Termos de indexação: Prótese total. Qualidade de vida. Satisfação do paciente.

\section{INTRODUCTION}

A demographic transition characterized by an aging population has been observed globally. This scenario is the result of a decrease in birth and mortality rates, as well as an increase in life expectancy. It is estimated that $21.1 \%$ of the world population will be 60 years old or more in 2050 , and that $80.0 \%$ of this demographic group will be living in countries with low and medium economic incomes [1].

In the specific case of Brazil, recent official epidemiological data indicate a significant growth in the older adult population in different segments of society [2]. As an illustration, according to data from the National Household Sample Survey, the number of older adults corresponded to $14.3 \%$ of the population in 2015 , and estimates for the 2030 s will be $18.0 \%$, with a progressive upward trend over the later decades $[2,3]$. This reality represents one of the great challenges of today, as it will characterize a scenario of growing demands in the country's public health sectors $[2,4-6]$.

In the field of oral health, data from the last National Epidemiological Survey (SB-Brasil) held in 2010 found that more than half of the older adult population did not have any teeth in their mouth (57.7\%). In addition to representing a mark of social inequality as a result of a mutilating care inheritance, this tooth loss also causes associated aesthetic and functional problems, especially regarding phonation and masticatory capacity. This hypoinsufficiency condition broadly potentiates fragility from the biopsychosocial point of view, with an emphasis on the nutritional aspect. This situation significantly interferes with the quality of life of older adults $[6,7]$.

The reality of this age group evidences the importance of expanding the offer of greater complexity actions in oral healthcare such as rehabilitation with dental prostheses. There has been an increase in dental services in the country since 2004 with the launch of the National
Oral Health Policy (Brasil Sorridente Program) through the Dental Specialization Centers (CEOs) and the Regional Dental Prosthesis Laboratories (LRPDs). However, the needs for dental treatments (59.5\%) and dentures (48.0\%) are still present for this population $[8,9]$.

In analyzing data on the use and need for dentures in the last Epidemiological Survey of Oral Health in Brazil [10] carried out by the Ministry of Health, it is important to highlight that it was identified that this criterion should also include a quality assessment of the dental prosthesis technique in use. Thus, four conditions were established to be investigated; retention, stability, fixation and aesthetics, indicating that the dentures would need to be replaced in the absence of at least one of them, and that this demand should consequently be registered. As an example, studies carried out with older Brazilian adults have found a great increase in the percentage of needing dentures in both arches, probably due to the need to replace the dentures which were in use [11].

The success or failure of prosthetic treatments can also be related to factors such as: interpersonal relationships between the professional and the patient, individual adaptive processes and oral health conditions [11]. Another aspect that influences oral rehabilitation concerns the anatomy of the alveolar ridge, since this structure can undergo a process of progressive and irreversible resorption after tooth loss, which is a condition that compromises the functional requirements of dental prosthesis retention and stability [12].

In a study by Corrêa et al. [13], it was found that the patients' self-perception regarding their dentures in use is subjective and complex. The evidence for this is based on the fact that some users claimed to be satisfied when their dentures did not hurt their mouth and did not interfere with chewing, speech, communication and appearance. However, other individuals reported that just being able to chew, even partially, was already satisfying. 
For Gabardo et al. [14], it is important to understand the subjective aspects of those rehabilitated with dentures, since there are individual variables that interfere with self-perception in relation to this type of dental treatment. This fact is considered fundamental for planning oral health services which aim to meet the needs of the population and reduce inequities.

In this context, it is essential to analyze the oral health conditions presented by denture users, especially the older adult group since they need to be made aware by the professional from the level of the reported information so that there is an adequacy between the quality of what is being offered and the personal demands of users.

In view of the above, the aim of the present study was to investigate the self-perception of older adults about rehabilitation with complete dentures performed in the Dentistry Course at the Federal University of Pernambuco (UFPE).

\section{METHODS}

This was a clinical-observational and cross-sectional study with individuals aged 60 years or over, rehabilitated with complete uni- or bimaxillary dentures at the UFPE Dentistry course clinic from October 2018 to April 2019. The study was approved by the Research Ethics Committee of this institution (CAAE: 87020818.5.0000.5208) and all patients who agreed to participate in the research signed the Informed Consent Form (ICF).

A total of 112 medical records of rehabilitated older adults with complete dentures were found in the referred service between the years 2015 to 2018 from the data provided by the Reception and Emergency Center (NAPA) from the Dentistry course at UFPE. Of this total, 60 patients were then contacted by phone, 23 of whom consented to participate in the research.

The inclusion criteria used for the participants were to be patients who had been using uni- or bimaxillary complete dentures for at least three months, aged 60 years or over, rehabilitated by the full-time dentistry courses at UFPE, and without a previous history of neurological diseases which would make participation in the study impossible.

The study excluded patients who did not consent to sign the informed consent form or who had diseases which prevented the use of the instruments used for data collection.
A form was developed by the researchers for the sample characterization containing sociodemographic, economic and medical-dental variables of patients using uni- or bimaxillary complete dentures who agreed to participate in the study.

The questionnaire adapted by Souza et al. [15] was used to assess the satisfaction level with the complete dentures in use, which was based on the original prepared by Čelebić \& Knezović-Zlatarić [16] and Čelebić et al. [17]. It is a self-perception instrument through which the respondents qualify their prostheses in use based on their experiences and impressions during its use by the terms: "unsatisfactory", "regular" or "satisfactory", from the following criteria: general quality of the prosthesis, aesthetics, comfort, retention, speech and chewing.

After this stage, the participants were intraorally examined by the researchers through digital palpation using an odontoscope and the dental chair reflector to identify the aesthetic-functional quality of the complete dentures in use. The adopted questionnaire was adapted by Costa et al. [18] based on the SB-Brasil [10] methodology from 2010, which uses the terms "satisfactory" and "unsatisfactory" for analyzing dentures according to the following criteria: retention, stability fixation, and aesthetics.

Using the SB-Brasil methodology [10], the retention of both types of complete dentures was assessed as "satisfactory" when there was resistance to the vertical displacements produced by the examiner's small touches. The professional subsequently performed small lateral movements to examine the stability. The stability was considered to be "satisfactory" if no noticeable displacement was observed or if there was a slight movement up to a maximum of $1 \mathrm{~mm}$. The prosthesis was evaluated with "unsatisfactory" fixation when it caused some type of lesion in the oral cavity, with the exception of candidiasis, as this is associated with difficulty to perform oral hygiene. Lastly, aesthetics were classified as "satisfactory" when there were no bruises, no fractures and the prosthesis was adequate to the patient's facial profile.

After applying the two instruments mentioned above, the participants answered the Oral Health Impact Profile (OHIP-14) questionnaire, recommended and validated by Slade [19] in 1997, which was previously translated in full by the researchers in order to be applied. This self-assessment instrument is considered a subjective indicator and was used to investigate the impact of 
prosthetic rehabilitation on the quality of life of the older adults surveyed.

The OHIP-14 investigates seven different domains related to oral health which can impact patients' quality of life, namely: functional limitation, physical pain, psychological discomfort, physical and psychosocial disability and social disadvantage. The answers provided were classified on a scale with the following codifications: $0=$ never, $1=$ rarely, $2=$ sometimes, $3=$ almost always, and $4=$ always.

The results from the data obtained with the instruments were then descriptively analyzed through absolute and percentage frequencies. The following measures were used for categorical variables: mean, standard deviation, median and minimum value, while the criterion adopted for the numerical variables was the maximum value.

The association between two numerical variables can be obtained by both the Spearman's correlation coefficient and the Student's t-test, noting that the latter specifically evaluates the null correlation. The Spearman's correlation coefficient was chosen in the present study due to normality rejection in at least one of the categories or variables, which was verified by the Shapiro-Wilk test.

Thus, the Spearman's correlation coefficient was used to investigate the possibility of a significant correlation between the technical quality of dentures in each arch and the general satisfaction level of the interviewees with their dentures, as well as to check if there was significant correlation between the seven domains of the OHIP-14 with the general satisfaction indexes of the self-perception questionnaire and with the general technical quality of the dentures analyzed by the researchers.

The data were entered into a Microsoft Office Excel 2016 spreadsheet and the IMB SPSS version 23 program was used to obtain the statistical calculations. The margin of error used in deciding the statistical tests was $5 \%$.

\section{RESULTS}

Regarding sociodemographic data, it was found that the majority of participants (56.5\%) were older adults, female $(73.9 \%)$ aged 60 to 69 years old, living in the city of Recife (PE) (69.6\%), single/separated/widowed (65.2\%) and had black skin color/race (52.2\%). Regarding economic variables, they were predominantly retired for length of service $(26.1 \%)$ with more than 4 years of formal education (65.2\%), and had a family income ranging from 1 to 3 minimum monthly salaries $(95.7 \%)$ (table 1$)$.

For the medical-dental variables, it was found that the most prevalent chronic and systemic diseases were hypertension (56.5\%) and diabetes (30.4\%). The majority of patients used complete dentures (65.2\%), and in some cases it was their first usage experience (21.7\%). Most

Table 1. Evaluation of the socioeconomic and demographic profile of the interviewed patients.

\begin{tabular}{|c|c|c|}
\hline Variables & $\mathrm{n}$ & $\%$ \\
\hline Total & 23 & 100.0 \\
\hline \multicolumn{3}{|l|}{ Age range } \\
\hline 60 to 69 & 13 & 56.5 \\
\hline 70 to 88 & 10 & 43.5 \\
\hline \multicolumn{3}{|l|}{ Gender } \\
\hline Male & 6 & 26.1 \\
\hline Female & 17 & 73.9 \\
\hline \multicolumn{3}{|l|}{ Race/Skin color } \\
\hline White & 10 & 43.5 \\
\hline Black & 12 & 52.2 \\
\hline Brown & 1 & 4.3 \\
\hline \multicolumn{3}{|l|}{ Civil status } \\
\hline Single/Separated/Widowed & 15 & 65.2 \\
\hline Married/Stable union & 8 & 34.8 \\
\hline \multicolumn{3}{|l|}{ Education } \\
\hline$<4$ years & 8 & 34.8 \\
\hline$\geq 4$ years & 15 & 65.2 \\
\hline \multicolumn{3}{|l|}{ Occupation } \\
\hline Retired & 6 & 26.1 \\
\hline Work at home & 5 & 21.7 \\
\hline Domestic employee & 5 & 21.7 \\
\hline Seamstress & 2 & 8.7 \\
\hline Businessman/woman & 1 & 4.3 \\
\hline Construction worker & 1 & 4.4 \\
\hline Taxi Driver & 1 & 4.4 \\
\hline Treasury Assistant & 1 & 4.4 \\
\hline Unemployed & 1 & 4.4 \\
\hline \multicolumn{3}{|l|}{ Family income } \\
\hline No income & 1 & 4.3 \\
\hline 1 to 3 minimum monthly salaries & 22 & 95.7 \\
\hline \multicolumn{3}{|l|}{ Origin } \\
\hline Recife & 16 & 69.6 \\
\hline Other municpalities of the Metropolitan Region & 6 & 26.1 \\
\hline Interior/countryside of Pernambuco & 1 & 4.3 \\
\hline
\end{tabular}


used it daily (60.9\%), for more than 1 year (34.8\%), and $(43.5 \%)$ did not return to the service or the professional who attended them for maintenance or make adjustments to their dentures.

When performing the clinical-dental examination to identify the presence of lesions and anatomical variations in the oral cavity from using complete dentures, the most prevalent findings were prosthetic stomatitis on the hard palate $(21.7 \%)$ and mandibular bone resorption (47.9\%) (table 2).

Regarding the satisfaction level of patients with using their complete dentures, it was evidenced that their general quality and aesthetics were considered by the majority as "satisfactory" (65.2\%). However, the best evaluated requirements were retention (69.6\%) and comfort (65.2\%) for the dentures in the upper arch. With regard to speaking ability with complete dentures, $65.2 \%$ rated it as "satisfactory"; however, regarding the interference of the dentures in chewing, most of the subjects reported that the results were average $(21.7 \%)$ or unsatisfactory (34.8\%) (table 3).

When assessing the technical quality of the dentures in use, it was observed that the lower complete dentures were unsatisfactory for retention (69.6\%), stability (69.6) and fixation (39.1\%) requirements (table 4).

Considering the 7 domains investigated and categorized by OHIP-14 such as: functional limitation, physical pain, psychological discomfort, physical, psychosocial disability and social disadvantage, it was identified that the complaints of the older adults were predominantly related to "physical pain" (in the oral cavity $8.7 \%$ and discomfort when eating, 34.8\%) and "physical disability" (impaired chewing $21.7 \%$ and swallowing $17.4 \%)$. These two investigated domains statistically stood out for presenting mean and standard deviation with values of $(1.63 \pm 1.48)$ and $(1.33 \pm 1.57)$, respectively (table 5$)$.

It was possible to verify a significant positive association between the technical quality index of dentures in each arch and that of users' satisfaction with them via Spearman's correlation coefficient, presenting values of 0.49 for the technical quality index of the upper dentures and 0.61 for the lower dentures (table 6).

The presence of a statistically significant correlation was also observed between the general satisfaction variables and the OHIP-14 domains, except for the
Table 2. Evaluation of the medical and dental variables of the interviewed patients.

\begin{tabular}{|c|c|c|}
\hline Variables & $\mathrm{n}$ & $\%$ \\
\hline Total & 23 & 100.0 \\
\hline \multicolumn{3}{|l|}{ Complete denture modality } \\
\hline Double & 15 & 65.2 \\
\hline Upper & 6 & 26.1 \\
\hline Lower & 2 & 8.7 \\
\hline \multicolumn{3}{|l|}{ Quantity of complete dentures already used } \\
\hline None & 5 & 21.7 \\
\hline 1 to 3 & 10 & 43.5 \\
\hline 4 to 6 & 4 & 17.4 \\
\hline 7 or more & 4 & 17.4 \\
\hline \multicolumn{3}{|l|}{ Time using current complete dentures } \\
\hline$<1$ year & 6 & 26.1 \\
\hline 1 year & 9 & 39.1 \\
\hline$>1$ year & 8 & 34.8 \\
\hline \multicolumn{3}{|l|}{ Daily use of the dentures } \\
\hline Yes & 14 & 60.9 \\
\hline No & 9 & 39.1 \\
\hline \multicolumn{3}{|l|}{ Reason for not using it daily ${ }^{1}$} \\
\hline Forgetting/lazy top put it in & 2 & 22.7 \\
\hline It moves with food in the mouth & 5 & 55.6 \\
\hline Causes pain and injury & 4 & 44.4 \\
\hline Accumulation of food & 4 & 44.4 \\
\hline Absence of anterior teeth & 1 & 11.1 \\
\hline \multicolumn{3}{|c|}{ Number of returns to the dentistry course for adjustments } \\
\hline None & 10 & 43.5 \\
\hline 1 to 3 & 9 & 39.1 \\
\hline More than 3 & 4 & 17.4 \\
\hline Occurrence of chronic and systemic diseases & 16 & 69.6 \\
\hline \multicolumn{3}{|l|}{ Type of disease ${ }^{2}$} \\
\hline Diabetes Mellitus & 7 & 30.4 \\
\hline Arterial hypertension & 13 & 56.5 \\
\hline Other & 4 & 17.4 \\
\hline Lesion occurrence in the oral cavity & 8 & 34.8 \\
\hline No lesion & 15 & 65.2 \\
\hline Prosthetic stomatitis on the palate & 5 & 21.7 \\
\hline Angular cheilitis & 2 & 8.7 \\
\hline Fibrous hyperplasia in the lower lip & 1 & 4.4 \\
\hline \multicolumn{3}{|l|}{ Anatomical variation in the oral mucosa } \\
\hline Mandibular bone resorption & 11 & 47.9 \\
\hline
\end{tabular}

Note: ${ }^{1}$ The percentages were obtained based on the total number of 9 patients who used the prosthesis daily. ${ }^{2}$ The percentages were obtained based on the total number of patients surveyed. Due to the possibility of the presence of more than one chronic disease, the sum of frequencies may be higher than the total number of patients. 
Table 3. Assessment of patient satisfaction with their complete dentures.

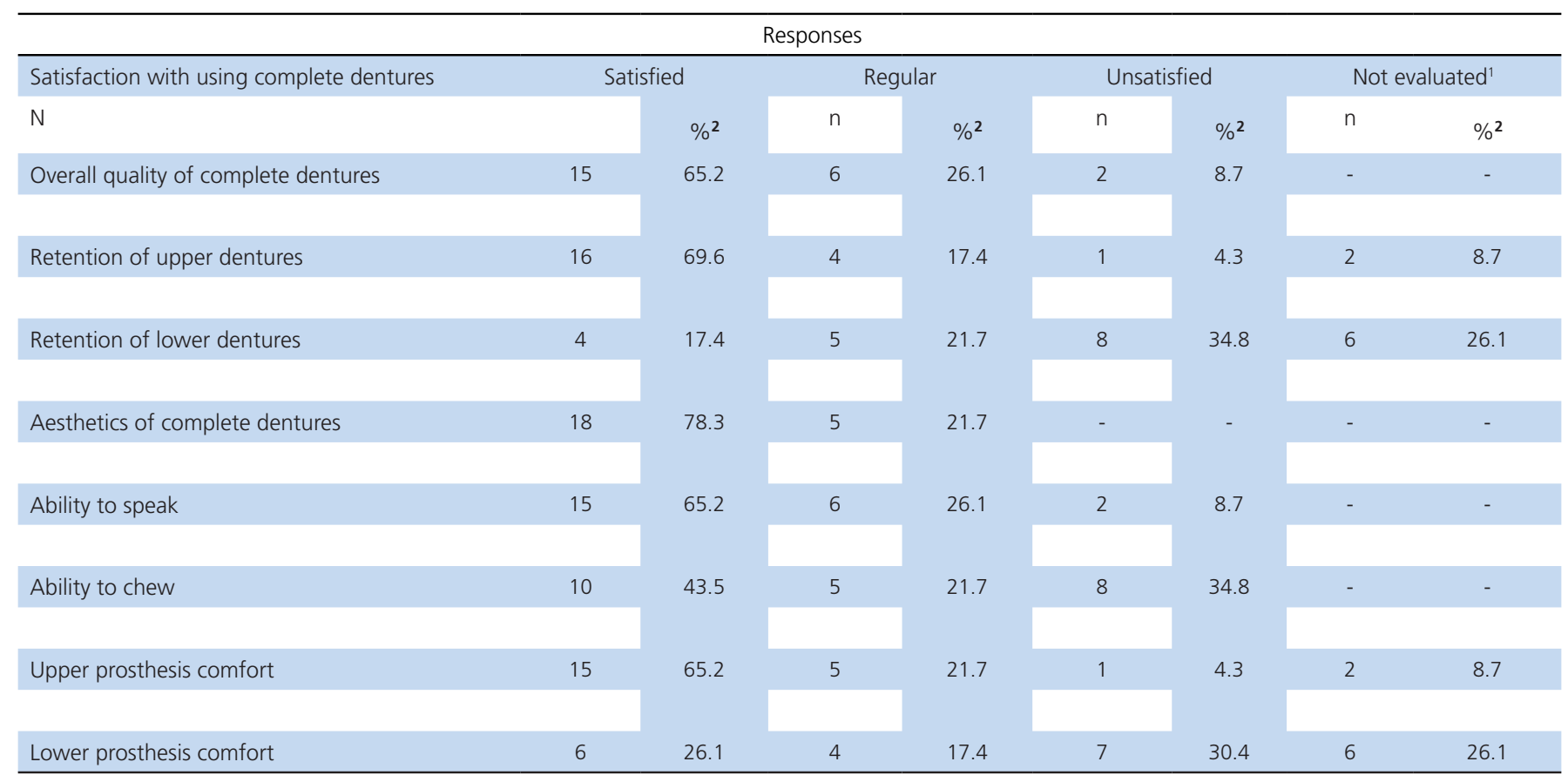

Note: ${ }^{T}$ The values in the "Not evaluated" category are equivalent to patients who did not mention the type of dental prosthesis. ${ }^{2}$ The percentage values were obtained based on the total of the 23 patients analyzed.

Table 4. Technical quality evaluation of the complete dentures.

\begin{tabular}{|c|c|c|c|c|c|c|}
\hline \multicolumn{7}{|c|}{ Responses } \\
\hline Technical quality & Satisfied & \multirow[b]{2}{*}{$\%^{(1)}$} & \multicolumn{2}{|c|}{ Unsatisfied } & \multicolumn{2}{|c|}{ Not evaluated (2) } \\
\hline N & & & $\mathrm{n}$ & $\%^{(1)}$ & $n$ & $\%^{(1)}$ \\
\hline \multicolumn{7}{|l|}{ Retention } \\
\hline Upper & 19 & 82.6 & 2 & 8.7 & 2 & 8.7 \\
\hline Lower & 1 & 4.3 & 16 & 69.6 & 6 & 26.1 \\
\hline \multicolumn{7}{|l|}{ Stability } \\
\hline Upper & 19 & 82.6 & 2 & 8.7 & 2 & 8.7 \\
\hline Lower & 1 & 4.3 & 16 & 69.6 & 6 & 26.1 \\
\hline \multicolumn{7}{|l|}{ Fixation } \\
\hline Upper & 21 & 91.3 & - & - & 2 & 8.7 \\
\hline Lower & 15 & 65.2 & 2 & 8.7 & 6 & 26.1 \\
\hline \multicolumn{7}{|l|}{ Aesthetics } \\
\hline Upper & 18 & 78.3 & 3 & 13.0 & 2 & 8.7 \\
\hline Lower & 17 & 73.9 & - & - & 6 & 26.1 \\
\hline
\end{tabular}

(1)The percentage values were obtained based on the total of the 23 patients analyzed. The values in the "Not evaluated" category are equivalent to patients who did not have the mentioned type of dental prosthesis.

"psychological discomfort" and "social incapacity" items. All values were negative, indicating an inverse relationship between the two variables, and were higher with the items "functional limitation" (-0.81), "physical pain" (-0.76), "physical disability" (-0.55) and "psychological disability" (-0.55) (table 6).

Lastly, no significant correlations were recorded regarding the technical quality variable of the upper 
Table 5. Distribution of the response frequency for each of the seven domains investigated, and the statistical values found from applying the Oral Health Impact Profile (OHIP-14) questionnaire.

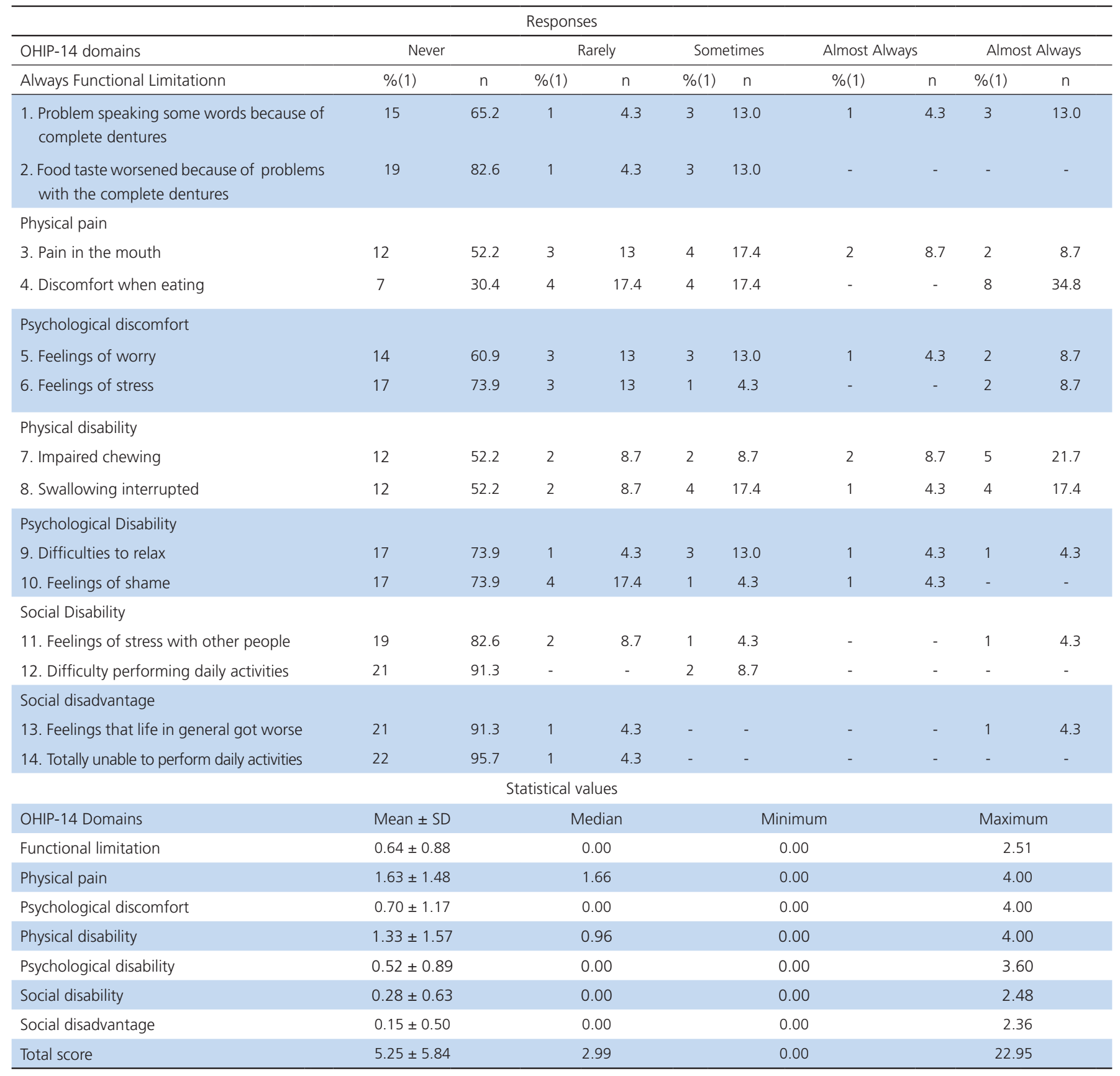

Note: (1) The percentage values were obtained from the total number of 23 patients analyzed.

prosthesis and the OHIP-14 domains, except for the "psychological capacity" item which presented a value of 0.45 with $p=0.039$. However, there were significant correlations between the technical quality variable of the lower dentures with "physical pain" (-0.85), "physical disability" (-0.68) and "functional limitation" $(-0.52)$ (table 6).

\section{DISCUSSION}

Different epidemiological studies estimate a significant increase in the older adult population in the world [1]. This reality is worrying in the case of Brazil, because it is related to a complex profile of demands which impacts health services, signaling the need to create 
Table 6. Spearman's correlation between the general technical quality index of the dentures in each arch and the overall satisfaction. Another correlation between the OHIP-14 domains, the general satisfaction of the patients and the technical quality of the dentures.

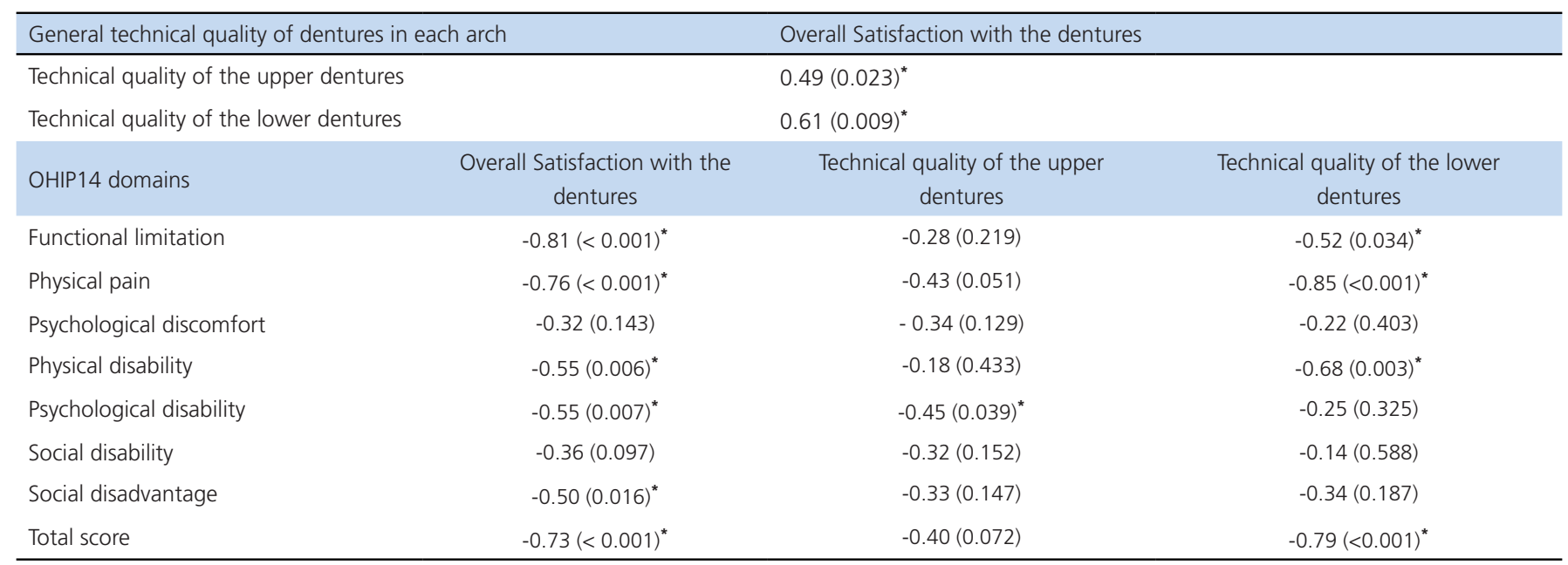

Note: $\left(^{*}\right)$ Statistically different from zero Significance level $(p>0.05)$.

specific care strategies and action instruments for this age group which is sometimes in a situation of social hypo-insufficiency $[2,4]$.

In the oral health field, Brazilian older adults still carry the legacy of Dentistry centered on curative and mutilating practices associated with edentulism, which consequently refers to the need for prosthetic treatments $[4,6,7]$. In this context, it is worth highlighting the importance of researching the patient satisfaction level in relation to rehabilitation using complete dentures (the objective of the present study), since the use of instruments which assess the self-perception of users of this type of prosthesis is one of the useful strategic components for assessing the quality of health services offered to the population. This is because they enable individuals to express their perceptions about the treatment performed, in addition to being able to be adopted in the clinical performance of professionals and in the preparation of plans by managers, aiming to improve health services.

In recently published studies, the use of different instruments such as: questionnaires, indexes or scales, to assess the satisfaction level in users of dental prostheses emphasizes the importance of this topic [15,20-22]. The purpose of these tools is centered on the patients' selfperception about criteria related to the general quality of the prostheses, their respective retention and stability, as well as the interference that these can cause in the ability to chew, swallow and speak. Other aspects which have also been extensively analyzed include discomfort, the presence of pain and aesthetic impairment. The results obtained from the patients' perspective with these investigations revealed that factors such as: masticatory capacity, retention and comfort of lower dentures constituted the main reported complaints of dissatisfaction [15,20-22].

The data obtained in the current study by applying the self-perception questionnaire to analyze the satisfaction level of older adults rehabilitated with complete dentures reinforce the idea that the main complaints are related to the lower/inferior dentures (table 3).

Considering the importance of investigating the patient's well-being with their dentures, previously conducted research found that the user satisfaction level can be influenced by certain parameters associated with the technical quality of the dentures. For example, when the surface of the dentures is properly polished, the orofacial muscle actions are able to act satisfactorily, contributing to the biomechanical principles of retention and stability. It has additionally been observed that pain, discomfort and functional limitation complaints reported by users were associated with poorly adapted dentures [21,23-25].

The clinical evaluation of the technical quality of the participants' dentures carried out by the professionals in the present study was based on the simplified methodology used in the last epidemiological survey on oral health implemented by the Ministry of Health [10] in 2010, according to which only the criteria of retention, stability, fixation and aesthetics were considered. This is because it was found that the majority of Brazilian older 
adults mainly needed new lower dentures due to the biomechanical principles of retention and stability being compromised.

According to Table 4, it was found that most of the upper complete dentures had good technical quality, while more than half of the lower prosthetic devices showed retention and stability problems. These results reinforce data obtained in previous studies using the same instrument $[18,21,24]$.

According to the clinical evaluation performed by the researchers, table 2 shows that $47.9 \%$ of the lower dentures were compromised in terms of adaptation. In this context, it is important to highlight that patients with marked reabsorption of the mandibular ridge, and consequently with impaired prosthesis functionality, often complain about dissatisfaction with their dentures, including those newly installed, even though they have been assessed by professionals as technically acceptable $[20,24,26]$.

Different studies have discussed the impacts that the satisfaction level with complete dentures can cause on the quality of life of users $[27,28]$. One of the instruments frequently used for this purpose has been the OHIP-14 index [19], as it assesses different domains such as: functional limitation, physical pain, physical and psychosocial disabilities, psychological discomfort and social limitation. More specifically, in using this tool with older adult complete denture users, Brazilian studies found that the upper dentures interfered little in the quality of life, while the lower dentures usually cause a certain level of stress, worry, physical pain and problems in chewing $[27,29]$. According to Table 5 , it was found that the main complaints were related to the domains "physical pain" and "physical disability". However, in the perception of older adults, unsatisfactory dentures interfered little in their ability to perform daily activities and interact socially. The proof of this is that the impacts of prosthetic devices in the "social disability" and "social disadvantage" domains were low.

Bearing in mind that previous studies $[21,22,26-28]$ have not concomitantly investigated satisfaction level, quality of life and technical quality in users of complete dentures, so therefore it was decided to perform a comparative analysis between the results of these three instruments in the present study. A statistically significant positive association was identified between the general technical quality of dentures in each of the arches in isolation and the general satisfaction of users. In other words, the better the technical quality of the dentures, the more satisfied the patient was. On the other hand, a significant inversely proportional correlation was obtained between the dissatisfaction level and quality of life considering the "functional limitation", "physical pain", "physical disability", "psychological disability" and "social disadvantage" domains, representing that the less satisfied the patient was with using their complete dentures, the greater the negative impacts it had on their personal life. It is additionally important to highlight that the general technical quality index of the dentures in the lower arch has more significant correlations with the OHIP-14 domains than the general technical quality of the upper dentures. This type of association shows that the lower the denture quality, the greater the impacts observed in the OHIP-14 domains (table 6).

Considering the specificity involved in oral healthcare of older adults when investigating selfperception about rehabilitation with dentures, one of the great difficulties was obtaining the consent of this population to participate in the research due to different biopsychosocial factors. For example, we can mention the general health status and the difficulty of accessing public health services due to social under-sufficiency.

Studies of this nature are important and deserve to be expanded, since it is highly recommended that all clinical procedures in rehabilitation treatments with complete dentures be based on a holistic conception of older adults on the part of professionals. In this context, it is essential to take into account self-perception in relation to patient satisfaction level with their dentures, since these can negatively affect the quality of life. Thus, the joint use of different instruments can become a valuable tool for planning effective strategies in health services, aiming to meet both the basic and specialized demands of this population segment.

\section{CONCLUSION}

From the results obtained it was possible to conclude that:

a) by evaluating the self-perception of older adults in relation to their satisfaction level with rehabilitation via complete dentures, it was found (from their perspective) 
that the main complaints were related to difficulties in their ability to chew, speak and with retention and the comfort of lower dentures.

b) by analyzing the technical quality of complete dentures from the aesthetic-functional point of view according to the dentist's perspective, it was found that the most compromised aspects were related to the retention and stability factors, mainly in relation to complete dentures.

c) unsatisfactory complete dentures caused negative impacts on the quality of life of users, especially in relation to comfort during meals, which was directly related to difficulty in chewing and swallowing.

\section{Collaborators}

All research stages were jointly carried out by both authors, namely: bibliographic research, preparation of the research project submitted to the UFPE Ethics Committee, data collection, data tabulation, interpretation of results, and writing the manuscript.

\section{REFERENCES}

1. Beard JR, Officer A, De Carvalho IA, Sadana R, Pot AM, Michel JP, et al. The world report on ageing and health: a policy framework for healthy ageing. The Lancet. 2016;387(10033):2145-2154. https://dx.doi.org/10.1016/ S0140-6736(15)00516-4

2. Miranda GMD, Mendes ACG, Silva ALA, Miranda GMD, Mendes ACG, Silva ALA. Brazilian population aging: current and future social challenges and consequences. Rev Bras Geriatr e Gerontol. 2016;19(3):507-519. https://dx.doi. org/10.1590/1809-98232016019.150140

3. Instituto Brasileiro de Geografia e Estatística. Pesquisa nacional por amostra de domicílios : síntese de indicadores 2015. Rio de Janeiro: IBGE; 2016. [2020 Jan 10]:105p. Available from: https://biblioteca.ibge.gov.br/visualizacao/livros/liv98887.pdf

4. Monteiro $A C L$, Sarmento $W E$, Queiroga ND, Machado $H C L$, Pereira DA, Lima SM, et al. Envelhecimento populacional: efetivação dos direitos na terceira idade. Pubvet. 2018;12(2):1-8. https://dx.doi.org/10.22256/pubvet.v12n2a29.1-8

5. Nico LS, De Andrade SSCA, Malta DC, Júnior GAP, Peres MA. Saúde bucal autorreferida da população adulta Brasileira: Resultados da Pesquisa Nacional de Saúde 2013. Ciênc Saúde Coletiva. 2016;21(2):389-398. http://dx.doi. org/10.1590/1413-81232015212.25942015

6. Miranda LCV, Soares SM, Silva PAB. Quality of life and associated factors in elderly people at a reference center. Ciênc Saúde Coletiva. 2016;21(11):3533-3544. https:// dx.doi.org/10.1590/1413-812320152111.21352015
7. Veras RP, Oliveira M. Aging in Brazil: The building of a healthcare model. Ciênc Saúde Coletiva. 2018 23(6):1929-1936. http:// dx.doi.org/10.1590/1413-81232018236.04722018

8. Pucca GA, Gabriel M, Araujo MED, Almeida FCS. Ten years of a national oral health policy in Brazil: Innovation, boldness, and numerous challenges. J Dent Res. 2015;94(10):13331337. http://dx.doi.org/10.1177/0022034515599979

9. Dalazen CE, Carli AD, Bomfim RA. Factors associated with the need for oral treatment of elderly Brazilians: a multilevel analysis. Ciênc Saúde Coletiva. 2018;23(4):1119-1130. http:// dx.doi.org/10.1590/1413-81232018234.27462015

10. Ministério da Saúde (Brasil). Secretaria de Atenção à Saúde. Secretaria de Vigilância em Saúde. SB Brasil 2010: Pesquisa Nacional de Saúde Bucal: resultados principais. Brasília: Ministério da Saúde; 2012. v.13 [DATA DE ACESSO]:1-5 Available from: https://bvsms.saude.gov.br/bvs/publicacoes/ pesquisa_nacional_saude_bucal.pdf

11. Colussi CF, Patel FS. Uso e necessidade de prótese dentária no Brasil: avanços, perspectivas e desafios. Heal Soc Chang. 2016;7(1):41-48. https://www.redalyc.org/articulo. oa?id=265346076006

12. Ribeiro JAM, Resende CMBM, Lopes ALC, Farias-Neto A, Carreiro AFP. The influence of mandibular ridge anatomy on treatment outcome with conventional complete dentures. Acta Odontol Latinoam. 2014;27(2):53-57. https://dx.doi. org/0.1590/S1852-48342014000200001

13. Corrêa HW, Bitencourt FV, Nogueira AV, Toassi RFC. Saúde bucal em usuários da atenção primária: análise qualitativa da autopercepção relacionada ao uso e necessidade de prótese dentária. Physis. 2016;26(2):503-524. https://dx.doi. org/10.1590/S0103-73312016000200009

14. Moysés SJ, Moysés ST, Olandoski M, Teresa M, Olinto A, Pattussi MP. Multilevel analysis of self-perception in oral health and associated factors in Southern Brazilian adults: a crosssectional study Análise em multinível da autopercepção em saúde bucal e fatores associados em adultos do Sul do Brasil : um estudo transver. Cad Saúde Pública. 2015;31(1):49-59. https://dx.doi.org/10.1590/0102-311X00037814

15. Souza RF, Terada ASSD, Vecchia MP Della, Regis RR, Zanini AP, Compagnoni MA. Validation of the Brazilian versions of two inventories for measuring oral health- related quality of life of edentulous subjects. Gerodontology. 2012;29(2):88-95. https://doi.org/10.1111/j.1741-2358.2010.00417.x

16. Čelebić A, Knezović-Zlatarić D. A comparison of patient's satisfaction between complete and partial removable denture wearers. J Dent. 2003;31(7):445-451. https://dx.doi. org/10.1016 / s0300-5712 (03) 00094-0

17. Čelebić A, Knezović-Zlatarić D, Papic M, Carek V, Baucic I, Stipetic J. Factors Related to Patient Satisfaction With Complete Denture Therapy. Journals Gerontol Ser A Biol Sci Med Sci. 2003;58(10):M948-M853. https://dx.doi. org/10.1093/gerona/58.10.M948

18. Costa APS, Machado FCA, Pereira ALBP, Carreiro AFP, Ferreira MÂF. Qualidade técnica e satisfação relacionada às próteses totais. Cienc e Saúde Coletiva. 2013;18(2):453-460. https:// dx.doi.org/10.1590/S1413-81232013000200016 
19. Slade GD. Derivation and validation of a shortform oral health impact profile. Community Dent Oral Epidemiol. 1997;25(4):284-289. https://dx.doi. org/10.1111/j.1600-0528.1997.tb00941.x

20. Marchini L. Patients' satisfaction with complete dentures: an update. Brazilian Dent Sci. 2014;17(4):5. https://dx.doi. org/10.14295/bds.2014.v17i4.1043

21. Limpuangthip N, Somkotra T, Arksornnukit M. Impacts of denture retention and stability on oral health-related quality of life, general health, and happiness in elderly Thais. Curr Gerontol Geriatr Res. 2019;2019. https://dx.doi. org/10.1155/2019/3830267

22. Tôrres ACSP, Maciel A de $\mathrm{Q}$, de Farias DB, de Medeiros AKB, Vieira FPTV, Carreiro A da FP. Technical quality of complete dentures: influence on masticatory efficiency and quality of life. J Prosthodont. 2019;28 (1):e21-26. https://dx.doi. org/10.1111/jopr.12703

23. Alfadda SA. The relationship between various parameters of complete denture quality and patients' satisfaction. J Am Dent Assoc. 2014;145(9):941-948. https://dx.doi.org/10.14219/ jada.2013.48

24. Rodolfo J, Jakymiu G, Corrêa GDEO. Levantamento de dados dos pacientes e condições das próteses totais bimaxilar confeccionadas pelo SUS no município de Pinhalzinho SC data survey of patients and conditions of dentures bimaxillary fabricated by SUS in the municipality pinhalzinho SC. Braz J Surg Clini Res. 2015;11:5-12.
25. Araújo M, Martins M, Soares A, Carvalho L, Gomes V, Ferreira $\mathrm{E}$, et al. Relationship between quality of complete dentures and user satisfaction at 1 and 5 years postinsertion. Int J Prosthodont. 2018;31(3):271-279. https://dx.doi.org/10.11607/ ijp.5477

26. Miranzi S, Alfredo M, Amuí M, Iwamoto H, Tavares S, Mara $D$, et al. Uso da prótese dentária entre idosos: um problema social. REFACS. 2015;3(1):1-5. https://dx.doi.org/10.18554/ refacs.v3i1.1029

27. Veronez FC, Sônego FGF, Ceretta RA, Zaccaron S, Ceretta LB. User satisfaction with complete dentures made by the public network of a city in southern Santa Catarina. RGO, Rev Gaúcha Odontol. 2014;62(2):123-127. https://dx.doi. org/10.1590/1981-8637201400020000032739

28. Paraguassu ÉC, Figueira KS, Lacerda JP, Guimarães UG, Gomes CE. Qualidade de vida e satisfação em usuários de prótese total no estado do Amapá, Brasil. Rev Eletr Acervo Saúde. 2019; (27):e876. https://dx.doi.org/10.25248/reas. e876.2019

29. Silva Júnior JB. Health promotion: Necessary and urgent action in the Americas. Ciênc Saúde Coletiva. 2019;24(11):3995-3995. https://dx.doi.org/10.1590/1413-812320182411.27292019

Received on: 20/2/2020

Final version resubmitted on: 4/5/2020

Approved on: 9/6/2020 